\title{
Tyre Pyrolysis Oil Properties and their Effect on Diesel Engine Performance, Emission and Combustion Characteristics: A review
}

\author{
Obadiah Maube $^{1}$ and Alfayo Alugongo ${ }^{2}$ \\ 1,2Department of Mechanical Engineering Vaal University of Technology, Private Bag X021, Vanderbijlpark, 1900, India.
}

\begin{abstract}
The rapid growth in the economy of many countries has led to high demand and over dependence on fossil fuels whose reserves are limited. Together with their undesirable environmental emissions, there has been need for identifying alternative fuels that are suitable for the diesel engines. Amongst other fuels, tyre pyrolysis oil (TPO) has been identified as a potential additive or supplement to the diesel fuel. When considering an alternative fuel, many factors are taken into consideration including emissions and performance in diesel engines. In in this review, published work on tyre pyrolysis oil with main focus on its use in diesel engines as an alternative is discussed. Production of tyre pyrolysis oil and the influence of pyrolysis process conditions on TPO yield are discussed. Optimum oil yield obtained during pyrolysis is within the range of $450-550^{\circ} \mathrm{C}$ depending on the reactor conditions. Properties of TPO are also discussed and compared to those of diesel and relevant standards. The effect of TPO and its blends on engine performance with emphasis on fuel consumption, thermal efficiency and emissions are also reviewed. Overall, the diesel engine performs better with low concentration of TPO in the Diesel/TPO blend than with higher concentration of TPO. This is because fuel properties such as such aromatic content, density, viscosity, Sulphur content and low Cetane number are higher compared to diesel.
\end{abstract}

Keywords: Tyre pyrolysis oil, diesel engine, emission, combustion, engine performance

\section{Introduction}

Waste disposal poses challenges especially with the tight regulations put in place by environmental protection agencies. One of these wastes is the scrap tyre. Tyres contain carbon black, steel cords, polyester and nylon fibre, steel bead wire, chemicals and fillers and up to $47 \%$ rubber [1]. Most of the tyre is composed of thermosetting polymers [2]. Because of the design of tyres and its properties, it is difficult to convert them into other components [3 5]. Rethreading can be done on tyres but only if it is not damaged [6]. They are designed to endure extreme operational conditions, and they take 80 to 100 years to biodegrade [3]. This makes the use of landfills as a way of disposing them unsuitable. Besides, they are bulky and cannot be easily compacted unlike any other landfill waste material. Although waste tyre does not pose a direct hazard, the volumes involved and the lack of proper disposal pose serious environmental concern. Five major problems in disposing of used tyres in developing countries have been described as follows [7]: The stock piles created by illegal dumping can lead to formation of breeding grounds for disease causing organisms thus pose risk to human health. There is risk of fire from the stockpiles leading to pollution. The concept of resource conservation "reuse" cannot be applied to tyres. Legal dumping costs are high leading to increase in illegal dumping, and lastly, space is becoming less as their volumes keep on increasing.

Although landfills have been used in South Africa (SA) before, it is being discouraged due to environmental concerns associated with it, this has led to illegal dumping or burning to recover steel [7]. It has been estimated that approximately 60 million scrap tyres are scattered all over South Africa with 11 million add to this figure every year [8]. Some of this scrap tyres are recycled while others are burned to recover steel and for heating purposes during winter, producing toxic fumes and liquids that may be harmful to human health and the environment. The rest is scattered in pile-stocks that act as breeding ground for mosquitoes and vermin.

One way of dealing with the tyre disposal problem could be through pyrolysis of scrap tyres to produce liquid fuel or hydrogen [9]. The liquid from pyrolysis can be used for various purposes including provision of fuel for the diesel engine. This is after some modification like distillation, Sulphur reduction and blending with diesel. For a fuel to be suitable for use in the diesel engine, a number of factors need to be critically looked at. They include fuel properties, engine performance in terms of thermal efficiency and fuel consumption, emission characteristics and most importantly engine durability concerns. The purpose of this review is to discuss the potential of tyre pyrolysis oil (TPO) as fuel for the diesel engine. The focus is on production of TPO, its fuel properties and compare to those conventional of diesel fuel and relevant standards. The effect of (TPO) and its blends on engine performance with emphasis on fuel consumption, thermal efficiency and emissions are also discussed.

\section{Tyre Pyrolysis Oil Production and Yield}

Pyrolysis is defined as the thermal degradation of organic components in the absence of air, the process yields liquid (oil), gas and solid (char) fractions $[2,10,11]$. According to a GCMS analysis carried out, TPO is a mixture of more than 200 compounds within the $\mathrm{C} 5-\mathrm{C} 15$ range [12]. The pyrolysis process was broken into four stages [13] in a study that was carried out to understand its mechanism using TG-MS and 
FTIR. The first stage took place below the temperature $320^{\circ} \mathrm{C}$ where water vaporization and plasticizer decomposition occurred. The second stage was between $320^{\circ} \mathrm{C}$ and $400{ }^{\circ} \mathrm{C}$ where natural rubber decomposed. The third stage involved the decomposition of synthetic fiber at between $400-520{ }^{\circ} \mathrm{C}$. Beyond $520{ }^{\circ} \mathrm{C}$ little change in weight loss was observed and this was the fourth stage.
Pyrolysis has been studied with conditions being varied with the aim of maximizing on the oil yield. These conditions are discussed in this section and summarized in Table 2.3.

Table 2.3. Reported yield at various operation conditions

\begin{tabular}{|c|c|c|c|c|}
\hline \multirow[t]{2}{*}{ Reference } & \multirow[t]{2}{*}{ Feed stock, reactor type and operating conditions } & \multicolumn{3}{|c|}{ Optimum oil Yield \% } \\
\hline & & Oil & char & gas \\
\hline$[14]$ & $\begin{array}{l}\text { Carried out in an externally heated pilot scale reactor at Temperature range } \\
\text { of between } 300-500^{\circ} \mathrm{C} \text { at various crushed tyre flow rate. }\end{array}$ & 45 & 50 & 5 \\
\hline [15] & $\begin{array}{l}\text { Reaction performed at temperature range of } 400-700{ }^{\circ} \mathrm{C} \text { in increments of } \\
100^{\circ} \mathrm{C} \text { and at various } \mathrm{N}_{2} \text { flow rates. Highest liquid yield observed at } 500^{\circ} \mathrm{C} \text {. } \\
\text { the effect of } \mathrm{N}_{2} \text { flow rate was negligible }\end{array}$ & 40.26 & 47.88 & 11.86 \\
\hline$[16]$ & $\begin{array}{l}\text { Tyre chips with bead, steel and fabric removed. Pyrolysis carried out in a } \\
\text { vacuum and reactor was externally heated. Temperature between } 450- \\
650^{\circ} \mathrm{C} \text {. and residence time of } 90 \text { minutes }\end{array}$ & 50 & 40 & 10 \\
\hline [17] & $\begin{array}{l}\text { Tyre chips from the periphery of the tyre were fed into fixed bed reactor, } \\
\text { heated externally in the absence of oxygen. Process carried out between } \\
\text { temperature range of } 450 \text { and } 650^{\circ} \mathrm{C} \text { at constant heating rate of } 5^{\circ} \mathrm{C} / \mathrm{min} \\
\text { and } 120 \text { min residence time. }\end{array}$ & 55 & 34 & 10 \\
\hline [18] & $\begin{array}{l}5-7 \mathrm{~cm} \text { tire particles externally heated in a fixed bed reactor. Temperature of } \\
450^{\circ} \mathrm{C} . \mathrm{N}_{2} \text { was used as a carrier gas. }\end{array}$ & 61 & 30 & 9 \\
\hline [19] & $\begin{array}{l}\text { Carried out at atmospheric pressure and temperature of between } 350^{\circ} \mathrm{C} \text { and } \\
600^{\circ} \mathrm{C} \text { in } 50^{\circ} \mathrm{C} \text { increments in a fixed bed reactor. Heating rate was } 5 \text { and } \\
35^{\circ} \mathrm{C} / \mathrm{min} \text {. The highest yield was obtained at } 400^{\circ} \mathrm{C} \text { and } 5^{\circ} \mathrm{C} / \mathrm{min} \text {. }\end{array}$ & 38.8 & 27.2 & 34 \\
\hline$[20]$ & $\begin{array}{l}\text { Granulated tyres fed in a continuous auger reactor at feed rate of about } 6.7 \\
\mathrm{~kg} / \mathrm{h} \text {. reaction temp of } 550^{\circ} \mathrm{C}, \mathrm{N}_{2} \text { used as carrier gas at } 5 \mathrm{~L} / \mathrm{min} \text {. Residence } \\
\text { time } 3 \mathrm{~min} \text {. }\end{array}$ & 42.6 & 40.5 & 16.9 \\
\hline
\end{tabular}

Younus et al., [21] carried out pyrolysis on automobile tyre between temperatures of $450^{\circ} \mathrm{C}$ and $650^{\circ} \mathrm{C}$ for a duration of 2 hours and 30 minutes. The yield from the process was $50 \%$ TPO, $40 \%$ pyro gas and $10 \%$ char by weight. The authors found that around $7.8 \mathrm{MJ} / \mathrm{kg}$ of energy was required for the process. Martinez et al., [20] produced tyre pyrolysis oil from trucks, tractors and cars in a continuous auger reactor. The reaction was done at optimum reactor conditions of $550{ }^{\circ} \mathrm{C}$ and $1 \mathrm{bar}$. The feedstock residence time was 3 minutes and flow rate was $6.7 \mathrm{~kg} / \mathrm{h}$. The liquid, solid and gas yields were found to be about $42.6 \%, 40.5 \%$ and $16.9 \%$ by weight respectively. Effects of tyre particle size, running time and reactor temperature on yield was investigated by Islam et al., [18] in a fixed bed reactor with nitrogen gas as a carrier gas. Tyre particle size of $5-7 \mathrm{~cm}$ was found to have a higher oil yield compared to that with particle size of $1-4 \mathrm{~cm}$. The authors suggested that this could be because the smaller particles of tyre were blown out of the reactor before complete devolatization. The authors also noted that the oil yield kept increasing with time. However, after 90 minutes reaction time, the oil yield remained constant. This was because all the volatile fractions had been exhausted. The reactor temperature was varied between $400^{\circ} \mathrm{C}$ and $500^{\circ} \mathrm{C}$. The optimum oil yield of $62 \%$ was obtained at a temperature of $450^{\circ} \mathrm{C}$. At low temperatures, char content was higher but reduced with increase in temperature while the gas yield was low and increased with increase in temperature. This is because the low temperature was not sufficient for complete devolatization resulting in high char and low oil and gas fractions. Banar et al., [19] noted a $29.5 \%$ reduction in liquid yield when the temperature was increased from the optimum temperature of $400{ }^{\circ} \mathrm{C}$ in that work to $600^{\circ} \mathrm{C}$, while there was an increase in gas yield with increase in temperature beyond the optimum point. This is probably due to further cracking of the liquid to gas $[2,16,19]$. In a similar work by Banar et al., [19], the effects of increasing heating rate on yield was studied. It was found that a lower heating rate of $5^{\circ} \mathrm{C} / \mathrm{min}$ had a higher oil yield of $38.8 \%$ compared to a heating rate of $35^{\circ} \mathrm{C} / \mathrm{min}$ that yielded $31.1 \%$ oil. The influence of tyre brand on yield and composition of pyrolysis products was investigated by Younus et al., [21]. Seven brands of tyres from different manufacturers were used in this work using a fixed bed reactor under similar conditions. The yields of char (37.7 - 38.7\% weight), oil (55.4 $-57.4 \%$ weight $)$ and gas $(2.7-5 \%$ weight $)$ for the different brands were found to be very similar. However, there were 
differences on composition of the products. The composition of gasses were found to vary with brand. There was similarity in their chemical compound but the concentration of the compounds varied. There was also a variation of elemental composition of the oils with brand. Pyrolysis has to be carried out in an oxygen free environment. Therefore, a vacuum can be created or an inert gas such as $\mathrm{N}_{2}$ may be used to prevent the tyre particles from burning due to the high temperatures in the reactor [15] and to carry away vapour from the reactor during the process [18]. Thus, the inert gas eliminates oxygen an that could cause to further oxidation and also prevents possibility of further reactions [12]. Aydin and Ilkilic, [15] investigated the effects of $\mathrm{N}_{2}$ flow rate on yield of pyrolysis products. The $\mathrm{N}_{2}$ flow rate was adjusted from $150 \mathrm{~cm}^{3} / \min$ to $350 \mathrm{~cm}^{3} / \mathrm{min}$ in increments of $50 \mathrm{~cm}^{3} / \mathrm{min}$. The authors did not find any significant differences in the yields of the products with change in flow rate. Catalytic pyrolysis was studied as a means of enhancing oil yield by Kar [22]. The author compared yield of catalytic and non-catalytic pyrolysis using expanded perlite as catalyst. The highest oil yield of non-catalytic pyrolysis was $60.02 \%$ by weight while that of catalytic pyrolysis was $65.11 \%$ by weight. This was a remarkable increment of $8.48 \%$ weight oil yield. Frigo et al., [14] investigated the effect of varying crushed tyre flow rate in a continuous pilot scale reactor. The flow rates were varied between $5.5 \mathrm{~kg} / \mathrm{h}$ and $14.5 \mathrm{~kg} / \mathrm{h}$. As flow rate increased, the solid yield was found to increase while the gas yield reduced. The oil yield kept increasing with increase in flow rate upto a maximum of $45 \%$ at $10 \mathrm{~kg} / \mathrm{h}$ flow rate then started to drop. This reactor had different sections where the temperatures were varied between $300^{\circ} \mathrm{C}-500{ }^{\circ} \mathrm{C}$. Edwin Raj et al., [11] studied the effect of temperature, particle size and feed rate on yield in a fluidized bed reactor. They found that temperature was the most significant factor affecting oil yield. The highest oil yield in this study was obtained at $440{ }^{\circ} \mathrm{C}$.

\section{Properties of Tyre Pyrolysis Oil}

There are several fuel properties that are critical for sound operation of the diesel engine. Some of these properties for TPO are shown in Table 2.4 and are discussed in the following section. Some authors have gone further to modify TPO by distillation. Distilled Tyre Pyrolysis oil (DTPO) has been found to have properties closer to diesel fuel than raw TPO.

Table 2.4. Properties of TPO reported in literature

\begin{tabular}{|c|c|c|c|c|c|c|c|c|c|}
\hline \multirow[t]{2}{*}{ author } & \multirow{2}{*}{ 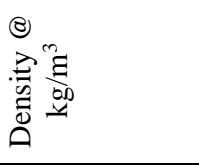 } & \multirow[b]{2}{*}{ 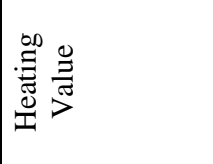 } & \multirow{2}{*}{ 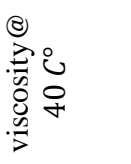 } & \multirow[b]{2}{*}{ 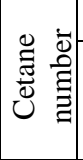 } & \multicolumn{5}{|c|}{ Elemental analysis \% } \\
\hline & & & & & $\mathrm{C}$ & $\mathrm{H}$ & $\mathrm{O}$ & $\mathrm{N}$ & $S$ \\
\hline [14] & $0.903 \mathrm{~kg} / \mathrm{L}$ & 41.96 & 2.90 & - & - & - & - & - & 0.97 \\
\hline [23] & $\begin{array}{c}920 \\
\text { @ } 20 C^{\circ}\end{array}$ & 39.2 & 5.4 & - & -- & - & - & - & - \\
\hline [24] & $\begin{array}{l}0.935 \\
15 C^{\circ}\end{array}$ & 43.8 & 3.2 & - & 81.18 & 10.92 & 4.62 & 1.85 & 0.031 \\
\hline [15] & $\begin{array}{c}0.945 \\
\text { @ } 20 C^{\circ}\end{array}$ & 43.34 & 3.8 & 44 & 86.87 & 10.07 & 1.67 & 1.184 & 0.906 \\
\hline [25] & $\begin{array}{c}880 @ \\
15 C^{\circ}\end{array}$ & 42.7 & 6.3 & 42 & - & - & - & - & - \\
\hline [16] & $\begin{array}{l}.9239 \\
15 C^{\circ} \\
\end{array}$ & 3 & 3.77 & - & 83.48 & 13.12 & 2.46 & 0.22 & 0.72 \\
\hline [18] & $\begin{array}{l}971 @ \\
15 C^{\circ}\end{array}$ & 41. & 4.8 & - & 80.30 & 5.18 & 10.13 & - & - \\
\hline [26] & $\begin{array}{c}0.945 \\
@ 20 C^{\circ}\end{array}$ & 43.34 & 3.8 & - & - & - & - & - & 0.9 \\
\hline [19] & $\begin{array}{l}820 @ 0 \\
15 C^{\circ} \\
\end{array}$ & 42.61 & $\begin{array}{c}0.95 \\
@ 50 C^{\circ}\end{array}$ & & 68.91 & 9.6 & 18.37 & 2.05 & 1.07 \\
\hline [20] & $\begin{array}{c}917 @ \\
15 C^{\circ}\end{array}$ & $\begin{array}{c}42.7 \\
\text { high } \\
40.49 \\
\text { low }\end{array}$ & 2.39 & & 86.19 & 10.33 & 0 & 0.79 & 0.83 \\
\hline [27] & $\begin{array}{c}944.4 @ 15 C^{\circ} \\
\end{array}$ & 39.9 & 5.06 & - & - & - & - & - & - \\
\hline [27] & $\begin{array}{r}904 @ \\
15 C^{\circ} \\
\end{array}$ & 40.9 & 2.16 & - & - & - & - & - & - \\
\hline [17] & $\begin{array}{l}935 @ \\
15 C^{\circ}\end{array}$ & 42.8 (gross) & 3.4 & & - & - & - & - & 0.95 \\
\hline$[17]^{*}$ & 871 & 45.6 (gross) & 1.7 & - & - & - & - & - & 0.03 \\
\hline
\end{tabular}




\section{Sulphur content}

Literature reviewed has reported a significantly high Sulphur content in TPO compared to that of diesel and biodiesel. Sulphur in TPO comes from the original feedstock. It is normally used to strengthen rubber in a process known as vulcanization. Frigo et al., [14] estimated that after pyrolysis, about $77 \%$ mass of the Sulphur in the tyre remains in the solid fraction while the remainder remains in the liquid fraction. The sulphur content of a fuel has significant effect on fuel emissions. It has been reported that [28] exhaust smoke, HC, $\mathrm{CO}$ and $\mathrm{SO}_{2}$ emissions reduced with reduction in sulphur content in the fuel whereas there was a remarkable decrease in particulate matter (PM) in the emissions. The authors explained that during combustion, sulphur is converted to $\mathrm{SO}_{2}$, thus consuming part of the oxygen that could have otherwise oxidized $\mathrm{CO}$ and $\mathrm{HC}$ to $\mathrm{CO}_{2}$ and $\mathrm{H}_{2} \mathrm{O}$. Sulphur reaction also leads to the formation of sulphates causing accumulation of carbon hence soot formation. Apart from emission concerns, sulphur can cause engine corrosion when exposed to high temperatures [29]. For these reasons, Sulphur levels should be kept as low as possible. SANS 342:2006 recommends a maximum value of $500 \mathrm{ppm}$. Studies have been carried out in an attempt to reduce sulphur content of TPO. Ilkilic and Aydin [26] investigated the effects of various rations of $\mathrm{Ca}(\mathrm{OH})_{2}$ as a catalyst during pyrolysis on sulphur content of TPO. The optimum amount of catalyst was found to be $5 \% \mathrm{Ca}(\mathrm{OH})_{2}$. This reduced the sulphur content of raw oil by $34 \%$. In a similar study [15], effects of using different catalysts such as $\mathrm{Ca}(\mathrm{OH})_{2}, \mathrm{CaO}$ and $\mathrm{NaOH}$ were studied. It was reported that using 5\% mass $\mathrm{Ca}(\mathrm{OH})_{2}$ catalyst during pyrolysis then followed by acid desulphurization using $10 \% \mathrm{H}_{2} \mathrm{SO}_{4}$ with a degree of purity of $98 \%$ reduced sulfur content by a remarkable $83.75 \%$. Koc and Abdullah [30] reported a reduction of sulfur content of TPO from $0.768 \%$ to $0.321 \%$ in their study. The method used by the authors involved mixing TPO with a binary solution containing tetraoctylammonium bromide and $\mathrm{HO}$, then exposing the solution to high intensity ultrasound for 5 minutes. Sulphur content has also been found to increase with pyrolysis reaction temperature. Aydin and Ilkilic [15] found that oil obtained at $500{ }^{\circ} \mathrm{C}$ had $3 \%$ higher sulphur content compared to that obtained at $400^{\circ} \mathrm{C}$.

\section{Cetane number and Cetane index}

This is a measure of the fuels ability to auto ignite on compression and it has direct influence on the ignition delay. Therefore, it determines the ignition quality of a fuel. SANS 342:2006 recommend a minimum Cetane number of 45 while ASTM Standard D 975-02 recommends a minimum of 40 . Typical diesel fuels have Cetane numbers in the range of 4550 [31]. The diesel engines operate well with fuels that have a Cetane number in the range of $40-55$ [25]. Very little literature has reported Cetane number of TPO. However, from Table 2.4, the reported values of 42 and 44 are well within the above reported range and ASTM D 975-02 specification, but lower than SANS 342:2006 recommended value. Higher Cetane number fuels have shorter ignition delay periods while low Cetane number fuels have longer ignition delay period, thus delaying start of combustion [24]. Increase in Cetane number leads to decline in PM and $\mathrm{HC}$ emissions [28]. Experimental determination of Cetane number is an expensive process, so sometimes a calculated value known as Cetane index (CI) is normally used to give an estimation of the Cetane number. However, this CI is only accurate when dealing with petroleum products rather than alternative fuels.

\section{Density}

The density of TPO is generally higher than that of diesel fuel, though after distillation (DTPO), that of DTPO approaches that of diesel $[17,28]$. Density of the fuel is also another important parameter. Since fuel is metered to the diesel engine on volume basis, a fuel of high density has more mass per unit volume than a fuel of low density. Therefore, a fuel with high density is likely to produce more engine power than a fuel with low density. At high speeds and loads, this could be a problem. The diesel fuel system is meant to inject the fuel on volume basis. Therefore, for the same volume a fuel with a larger density will have more fuel being injected into the combustion chamber. This will lead to a rich mixture, thus leading to smoke emission. SANS 342:2006 only sets a minimum limit of density at 800 $\mathrm{kg} / \mathrm{m}^{3}$. The upper limit is not set. The density of TPO is well above this value and higher than that of diesel. Another observation is that $\mathrm{NO}_{\mathrm{x}}$ emission increase with increase in density [27, 32].

\section{Viscosity}

When a fuel is injected into the cylinder, it will break into droplets, mix with air and vaporize before combustion takes place. For proper combustion, the air fuel mixture must be uniform. The quality of spray, air fuel mixing and distribution of fuel droplets in the cylinder determines the quality of combustion in the cylinder. This property is normally attributed to viscosity. From Table 2.4, the lowest reported viscosity of TPO is $2.39 \mathrm{cST}$, though most of the other reported values are higher than that of diesel. The highest reported value being 6.3 cST. This value is twice more than that of diesel at $2.79 \mathrm{cST}$ [20]. SANS 342:2006 limits the viscosity range of diesel fuel to between 2.2 - $5.3 \mathrm{cST}$. High viscosity fuels also lead to longer ignition delay since it will result in poor atomization, thus, more fuel air mixture will be prepared during the premixed combustion phase [16]. Low viscosity leads to better fuel preparation during ignition delay leading to better combustion.

\section{Heating value}

The most important property of a fuel is the amount of energy produced during combusting. This is measured using the Heating Value or Calorific Value. It shows the amount of heat released per unit mass of fuel burned and it influences power and fuel consumption of the engine. From reported values in Table 2.4, TPO has a remarkable heating value of $38-44$ $\mathrm{MJ} / \mathrm{kg}$. However, this is slightly lower than the reported value of diesel of $45.13 \mathrm{MJ} / \mathrm{kg}$ [20]. Carbon content in hydrocarbon fuel is an indicator of energy content of a fuel [24]. As seen in 
International Journal of Engineering Research and Technology. ISSN 0974-3154 Vol.13, No.3 (2020), pp. 520-527

(C) International Research Publication House. https://dx.doi.org/10.37624/IJERT/13.3.2020.520-527

the 2.4, TPO has lower carbon content compared to diesel fuel and this explains the low energy content of TPO compared to that of diesel.

\section{Engine performance}

Research has been carried out to investigate the effects of using TPO on engine performance and emissions $[12,14,16,21,23$, 24]. Diesel fuel was used as the reference fuel so this performance was being compared to that of TPO. Effects of blends of TPO with diesel, biodiesel and additives such as ignition improvers have been reviewed in this section.

Murugan et al., [16] prepared three blends of 10\%, 30\% and $50 \%$ TPO with diesel fuel by volume and tested in a single cylinder stationary air cooled direct injection diesel engine. The results were reported at full load. The Brake Thermal efficiency was found to be 29.5, 27.2, 28.5 and $28.9 \%$ for diesel, TPO 10, TPO 30 and TPO 50 respectively. Among the blends, TPO 30 showed better performance at all loads. The $\mathrm{CO}, \mathrm{NO}_{\mathrm{x}}$ and $\mathrm{HC}$ emissions for the blends were higher when the engine was running on the blends than when running on diesel fuel. The $\mathrm{CO}$ concentration increased by an average of $12 \%$ compared to that of diesel. Apart from TPO 30, the rest of the blends exhibited high smoke emissions. Another study was carried out with a blend containing $10 \%$ TPO in diesel at a constant speed of 2200rpm at different torques of 3.75, 7.5, 11.25 and $15 \mathrm{Nm}$. Uyumaz [12]. In the work it was noted that the engine tended to knock with TPO10 and it increased with load. The fuel Specific Fuel Consumption and Indicated Thermal efficiency was found to be higher and lower respectively compared to diesel.

Frigo et al., [14] compared blends of 5 - 45\% TPO with diesel. There was no significant change in engine performance with blends containing up to $20 \%$ TPO compared to that of diesel fuel. However, the engine became unstable when running on fuel with above $40 \%$ TPO concentration. Brake Specific Fuel Consumption (BSFC), Torque, Power output and emissions of an engine fueled with blends of TPO and diesel were investigated by [26]. In that study TPO was blended to 5 (TPO5), 10(TPO10), 15(TPO15), 25(TPO25), 35(TPO35) and $75 \%$ (TPO75) by weight with diesel fuel. Engine power was found to reduce with increase in TPO concentration in the blend while the BSFC increased with increase in TPO concentration. The torque and engine power of TPO 100 was $11.86 \%$ and $16.6 \%$ lower than that of diesel while the BSFC of TPO was found to be $12 \%$ higher. HC and CO for TPO 100, 75 and 50 were much higher than those of lower blends (TPO 15, 25 and 35). $\mathrm{SO}_{2}$ increased with increase in TPO concentration in the blend. This study concluded that blends of up to TPO 35 could be used in diesel engines without engine modifications. TPO $50-100$ was found to be unsuitable due to the high $\mathrm{CO}, \mathrm{HC}$, $\mathrm{SO}_{2}$ and smoke emissions. Kumar et al., [33] also noted that a blend containing 20\% TPO with diesel engine produced optimum performance in terms of thermal efficiency and BSFC while keeping emissions low.

The effects of TPO that has been improved by distillation on engine performance and emissions was studied [27]. The experiments were performed at full load and varying speed.
Blends containing DTPO 10, 30, 50, 70 and 90\% with diesel were prepared for this work. There was no significant difference in the torque and power output for upto 70\% DTPO. There was no significant difference in Brake Specific Energy Consumption (BSEC) with blends of upto 50\% DTPO. Beyond $50 \%$, there was an increase in BSEC at medium loads. At low and high engine speeds, the thermal efficiency of the blends was higher than that of diesel. There was a tendency of $\mathrm{NO}_{x}$, $\mathrm{CO}$ increasing with increase in DTPO concentration while the opposite trend was noted for $\mathrm{HC}$, smoke opacity.

Effects of ignition improver, Diethyl Ether (DEE) as an additive to TPO on diesel engine performance was investigated by Hariharan et al., [24]. DEE was inducted into the engine through intake air at flow rates of $65 \mathrm{~g} / \mathrm{h}, 130 \mathrm{~g} / \mathrm{h}$ and $170 \mathrm{~g} / \mathrm{h}$. $\mathrm{HC}, \mathrm{CO}$ and smoke emissions were higher than that of diesel, but there was an improvement with increase in DEE flow rate. NOx was found to be lower than that of diesel. Due to the low Calorific Value of DEE, the thermal efficiency reduced while the BSFC increased with increase in DEE flow rate.

The use of TPO and Jatropha Methyl Ester (JME) blends on performance of the diesel engine has been investigated by Sharma and Murugan [23]. TPO from $10 \%$ to $50 \%$ in increments of $10 \%$ by volume was blended with Jatropha Methyl Ester. JMETPO 20 exhibited the best performance. The thermal efficiency of this blend at high load was found to be close to that of diesel while the BSEC was $7.8 \%$ higher than that of diesel at high load. $\mathrm{CO}, \mathrm{HC}$ and smoke emissions at full load were lower than those of diesel by $9.09,8.6$ and $26 \%$ respectively while $\mathrm{NO}_{2}$ was $24 \%$ higher. To reduce emissionsand improve performance a study was carried out by adding Carbon nanotubes and Cerium oxide nano particles [34] to blends of JME, TPO and diesel. The results showed improved thermal efficiency, lower fuel consumption and emissions (CO, HC and NOx) using when 100ppm of nano additives was added to the fuel.

The use of ternary blends containing biodiesel, diesel and TPO in engine performance was investigated by [30]. Five fuel samples were used in this study. B5D95, B10D90, B5T5D90, $\mathrm{B} 10 \mathrm{~T} 10 \mathrm{D} 80$ and D100. B, T and D represent biodiesel, TPO and diesel respectively while the numeric value represent the percentage concentration. In terms of power, torque, fuel consumption and CO emissions, B10T10D80 exhibited better overall performance. B10T10D80 produced the highest power, torque and lowest fuel consumption compared to other blends. The authors suggested that future research need to focus on improving fuel properties with pre-treatment and identifying the ideal biodiesel, TPO and diesel blends that will produce optimum engine performance with reduced emissions.

The general observation was that tyre pyrolysis oil is not suitable for diesel engine without blends and additives. The higher the blend concentration the higher the emissions. The fuels with high TPO concentration tended to produce lower torque and power. This could be due to the lower heating energy than that of diesel fuel. Brake Specific Fuel Consumption (BSFC) is an indication of the mass required to produce a unit output of Brake Power. Using TPO, the same amount of power as the one produced by diesel was able to be achieved. However due to the low energy content of TPO, more 
fuel will be required. This will lead to the reported high fuel consumption and low Brake thermal efficiency (BTE).

\section{Combustion Analysis of Tyre Pyrolysis Oil}

\section{Ignition delay}

TPO has a lower Cetane number and higher viscosity compared to that of diesel, thus the engine is expected to exhibit a longer ignition delay. [16] reported an increase ignition delay with increase in TPO Diesel blends. This was attributed to the high viscosity of TPO and its blends compared to diesel. Hariharan et al., [24] investigated the effect of DEE in ignition delay of an engine running on TPO. It was found that the ignition delay reduced with increase in quantity of DEE. The Cetane number of DEE (125) is much higher than that of diesel, therefore it reduced the ignition delay period compared to that of diesel. Martinez et al.,[20] found that there was little difference between the ignition delay of TPO5 and that of diesel. This was attributed to the small difference in Cetane number and the lower viscosity of the fuel in this blend partly compensated with improved combustion. In another study [23] it was reported that an engine running on JME, JMETPO10 and JMETPO20 had a shorter ignition delay compared to that of diesel fuel. This was attributed to the higher Cetane number of JME and the presence of oxygen in JME that resulted in improved reaction and combustion.

\section{Cylinder peak pressure and rate of pressure rise}

The peak pressure and the rate of pressure rise is linked to the ignition delay. The rate of pressure rise determines the smoothness of engine operation. A rapid rise will lead to vibrations while a slower pressure rise will lead to a more smooth operation. When the ignition delay is long, a large amount of charge will accumulate in the cylinder during the ignition delay period. This will rapidly burn during the uncontrolled ignition leading to high peak pressure and rate of pressure rise. Blends of TPO and diesel have been found to have high peak pressure and higher rate of pressure rise compared to diesel. Blends of JMETPO have been found to have lower rate of pressure rise compared to diesel, apart from JMETPO 10 and 20 while the peak pressure increased with the quantity of TPO in the blend [23]. JMETPO30 and JMETPO 50 had longer ignition delays due to reduction of $\mathrm{CN}$ with increase in TPO in the blend.

\section{Analysis of Engine emissions}

During combustion, exhaust emissions such as $\mathrm{CO}, \mathrm{NO}_{\mathrm{x}}, \mathrm{HC}$, $\mathrm{SO}_{2}$, and particulates are as a result of incomplete combustion.

Unburned hydrocarbon (UBH) is an important indication of combustion efficiency and is composed of fuel that is not completely burned [35, 36]. Hydrocarbon emissions are normally as a result of incomplete combustion. The amount of UBH emitted depend on engine operating conditions, fuel properties and air fuel mixing in the combustion chamber [36]. Most literature reported that the higher the concentration of
TPO in a blend the higher the HC emissions of the engine. [16] studied the effects of load on HC emissions on TPO-DF blends. The authors noted higher emissions at full and low loads while blends with higher TPO content resulted in higher HC emissions. The high aromatic nature of TPO could also course increase of unburned hydrocarbon. One study [27] reported lower HC emission for blends of upto $50 \%$ TPO with diesel fuel and higher $\mathrm{HC}$ for blend with more than 50\%. The viscosity of the oil in that work was less than that of diesel. JMETPO blends of 10 and 20 percent showed lower HC emissions compared to reference diesel fuel due to better combustion of JME [23].

$\mathrm{CO}$ is a colourless and very toxic gas and its emission should be kept as low as possible. $\mathrm{CO}$ emissions depend on air fuel ratio, rich mixture tends to increase $\mathrm{CO}$ emission [35] while at lean mixtures, and the $\mathrm{CO}$ will be further oxidized to $\mathrm{CO}_{2}$. While some authors have reported an increase in $\mathrm{CO}$ with increase of TPO in the blend, others have found no significant difference. Ilkilic and Aydin [26] observed a reduction in $\mathrm{CO}$ emissions with increase in engine speed for both diesel fuel and blends with TPO. This is because as engine speed increases, the air movement in the cylinder creates a more uniform air fuel mixture leading to improved combustion, and consequently lower $\mathrm{CO}$ emissions. Though in general, the $\mathrm{CO}$ content from TPO and its blends in that work was higher than that of diesel fuel. Dogan and Ozdalyan [27] observed a reduction in $\mathrm{CO}$ emissions with increase in TPO content in blends at lower speed (1400 \& $2000 \mathrm{rpm})$ while at higher speed (2600-3200 rpm) an opposite trend was noted. However, these differences in $\mathrm{CO}$ emissions were not significantly different to those of diesel fuel.

$\mathrm{NO}_{\mathrm{x}}$ emissions is formed by a series of reactions between nitrogen and oxygen in the air. Both TPO [17] and DTPO [27] blends with diesel exhibited high $\mathrm{NO}_{\mathrm{x}}$ emissions compared to diesel fuel. The effect of speed on $\mathrm{NO}_{\mathrm{x}}$ emission was studied by Ilkic and Aydin [26]. They reported that at low and medium speeds TPO100 and blends with high concentration of TPO exhibited significantly low $\mathrm{NO}_{\mathrm{x}}$ emissions, the opposite trend was noted at high speed. $\mathrm{NO}_{\mathrm{x}}$ emissions are mainly affected by aromatic content, cylinder gas temperature, density and residence time [16, 28, 32, 36, 37]. Fuels with high aromatic content exhibit longer ignition delay thus leading to increase if $\mathrm{NO}_{\mathrm{x}}$. The aromatic content of TPO is higher than that of diesel therefore it is expected that the $\mathrm{NO}_{\mathrm{x}}$ values will increase with TPO increase in blend.

Limited literature was found on $\mathrm{SO}_{2}$ emission. An increase in $\mathrm{SO}_{2}$ with use of TPO or with increase in TPO concentration in blends was reported [26]. In that work, it was found that $\mathrm{SO}_{2}$ increased almost linearly with TPO in blends. This was probably due to the high sulphur content in TPO. The Sulphur content of TPO in their work was $4.5 \%$ higher than that of diesel.

Smoke consists of soot in exhaust gas. Smoke Opacity is essential since it shows the amount of pollutants emitted, higher smoke may indicate higher particulate matter [26]. It was found that TPO10 and TPO50 [16] had similar smoke emission levels but slightly higher than that of diesel. This was attributed to the higher aromatic content of TPO. In a similar study, Ilkilic and 
Aydin [26] found that all blends exhibited higher smoke opacity levels than that of diesel. The reasons given were the high density and large TPO molecules could have caused poor atomization. Smoke opacity of DTPO was found to reduce with increase in DTPO concentration in the oil [27]. The low flash point and viscosity of DTPO was attributed to this observation. Low flash point for a fuel means high volatility.

In general, any factor that causes incomplete combustion will also lead to increase in $\mathrm{HC}$ and $\mathrm{CO}$ emissions. These could include higher density, poor volatility, high aromatic content, rich fuel mixtures, lower Cetane number, longer ignition delay and higher carbon residue [16, 26, 27]. Diesel engines are designed to run on a lean mixture. The density of TPO is generally higher than that of diesel so when fuel is being injected into the combustion chamber, due to the higher density more fuel will be injected into the chamber on mass basis leading to a rich mixture. It has been shown elsewhere [28] that emissions such as exhaust smoke, PM, NOx, $\mathrm{HC}$ and $\mathrm{CO}$ reduce with decline of fuels aromatic content. [20] found the aromatic content of TPO to be $65.2 \%$, which was much higher than that of diesel at $29.8 \%$. This could also explain why the emissions of TPO is higher than that of diesel.

\section{CONCLUSION}

The main products of tyre pyrolysis are liquid oil, gas and char. Given that the oil yield can go up to $65 \%$, pyrolysis presents a proper way of tyre disposal especially in developing countries where there are large stockpiles of tyres like in South Africa. The quantity and quality of tyre pyrolysis products depend on reactor type, tyre particle size, heating rate and pyrolysis temperature, as opposed to tyre composition. The optimum oil yields can be obtained in temperatures ranging between $450-$ $550^{\circ} \mathrm{C}$ depending on reactor design operating conditions. Beyond this optimum temperature, the gas yield increased because the oil and char was being volatized to gas. At lower temperatures the solid yield was high because the temperatures are not sufficiently high enough thermally degrade if to gas and oil. The use of catalyst has a remarkable effect on yield. The liquid from pyrolysis can be used for many purposes including fuel for the internal combustion engine after some modification like Sulphur reduction or blending with diesel or other fuels. The diesel engine is optimized for diesel fuel. Thus for any other fuel to run in the diesel engine, its properties must be as close as possible to those of diesel fuel. The properties of TPO have a significant effect on engine performance and emissions. Due to this, TPO is not suitable for use in the diesel engine in raw state or without modifications to the engine. These properties include high aromatic content, density, viscosity, Sulphur content and low Cetane number compared to diesel. However, there is significant improvement in the performance if the TPO is distilled or blended with other fuels such as biodiesel, diesel or use of ignition improvers. DTPO has properties closer to diesel than Raw TPO. Blends containing low TPO concentration offer better performance and emission characteristics than blends containing high TPO concentration. TPO diesel Blends containing up to $30 \%$ TPO concentration can produce acceptable performance. Beyond 50\% TPO the engine becomes erratic at high loads and above $70 \%$ TPO concentration may not be able to run. A pretreatment process of TPO can be used to reduce Sulphur content to acceptable levels. Ternary blends of TPO, biodiesel and diesel seem to produce better performance. Therefore, more study should focus on this areas since biodiesel has properties such as high Cetane number and oxygen content that can make up for the same deficiencies in TPO. Brake thermal efficiency increased with increase in TPO in the blend but was lower than that of diesel while the thermal efficiency of DTPO was higher than that of diesel.

\section{REFERENCES}

[1] Anne and E. Russ. 2006. The composition of a tyre: Typical components. The Waste \& Resources Action Programme. Banbury Oxford UK, .

[2] Williams P. T. 2013, "Pyrolysis of waste tyres: A review". Waste Manage. 33(8), pp. 1714-1728.

[3] Martínez J. D., Lapuerta M., García-Contreras R., Murillo R. and García T. 2013, "Fuel properties of tire pyrolysis liquid and its blends with diesel fuel". Energy Fuels 27(6), pp. 3296-3305.

[4] Verma P., Zare A., Jafari M., Bodisco T. A., Rainey T., Ristovski Z. D. and Brown R. J. 2018, "Diesel engine performance and emissions with fuels derived from waste tyres". Scientific Reports 8(1), pp. 1-13.

[5] S. Kordoghli, M. Paraschiv, M. Tazerout and F. Zagrouba, "Waste tyres pyrolysis: Managing the environmental hazards of scrap tyres," in IREC2015 the Sixth International Renewable Energy Congress, 2015, pp. 1-6.

[6] Roy C., Chaala A. and Darmstadt H. 1999, "The vacuum pyrolysis of used tires: End-uses for oil and carbon black products". J. Anal. Appl. Pyrolysis 51(1), pp. 201-221.

[7] N. Nkosi, E. Muzenda, J. Zvimba and J. Pilusa, "The current waste generation and management trends in south africa: A review," in International Conference on Integrated Waste Management and Green Energy Engineering, 2013, pp. 303.

[8] Recycling and Economic Development Initiative of South Africa (REDISA). . The Waste Tyre Problem. Available: http://www.redisa.org.za/about/waste-tyreproblem/.

[9] Hürdoğan E., Ozalp C., Kara O. and Ozcanli M. 2017, "Experimental investigation on performance and emission characteristics of waste tire pyrolysis oildiesel blends in a diesel engine". Int J Hydrogen Energy 42(36), pp. 23373-23378.

[10] Alcala A. and Bridgwater A. 2013, "Upgrading fast pyrolysis liquids: blends of biodiesel and pyrolysis oil". Fuel 109pp. 417-426.

[11]Edwin Raj R., Robert Kennedy Z. and Pillai B. 2013, "Optimization of process parameters in flash pyrolysis of waste tyres to liquid and gaseous fuel in a fluidized 
bed reactor". Energy Conversion and Management 67pp. 145-151.

[12] Uyumaz A., Aydoğan B., Solmaz H., Y1lmaz E., Hopa D. Y., Bahtli T. A., Solmaz Ö and Aksoy F. 2019, "Production of waste tyre oil and experimental investigation on combustion, engine performance and exhaust emissions". Journal of the Energy Institute 92(5), pp. 1406-1418.

[13] Han J., Li W., Liu D., Qin L., Chen W. and Xing F. 2018, "Pyrolysis characteristic and mechanism of waste tyre: A thermogravimetry-mass spectrometry analysis". J. Anal. Appl. Pyrolysis 129pp. 1-5.

[14]Frigo S., Seggiani M., Puccini M. and Vitolo S. 2014, "Liquid fuel production from waste tyre pyrolysis and its utilisation in a Diesel engine". Fuel 116pp. 399-408.

[15] Aydın H. and İlkılıç C. 2012, "Optimization of fuel production from waste vehicle tires by pyrolysis and resembling to diesel fuel by various desulfurization methods". Fuel 102(0), pp. 605-612.

[16] Murugan S., Ramaswamy M. and Nagarajan G. 2008, "The use of tyre pyrolysis oil in diesel engines". Waste Manage. 28(12), pp. 2743-2749.

[17] Murugan S., Ramaswamy M. and Nagarajan G. 2008, "A comparative study on the performance, emission and combustion studies of a DI diesel engine using distilled tyre pyrolysis oil-diesel blends". Fuel 87(10), pp. 21112121.

[18] M. Islam, M. Khan and M. Alam, "Production and characterization of scrap tyre pyrolysis oil and its blend," in Proceedings of the International Conference on Mechanical Engineering, 2003, .

[19] Banar M., Akyıldız V., Özkan A., Çokaygil Z. and Onay Ö. 2012, "Characterization of pyrolytic oil obtained from pyrolysis of TDF (Tire Derived Fuel)". Energy Conversion and Management 62pp. 22-30.

[20] Martínez J. D., Rodríguez-Fernández J., SánchezValdepeñas J., Murillo R. and García T. 2014, "Performance and emissions of an automotive diesel engine using a tire pyrolysis liquid blend". Fuel 115pp. 490-499.

[21] Younus S. M., Kumar V. R. and Rao D. Y. H. 2013, "Performance and Emissions Characterstics of Diesel Engine Fueled With Tyre Pyrolysis Oil\&Diesel Blends with Additives"2(5), pp. 32-37.

[22] Kar Y. 2011, "Catalytic pyrolysis of car tire waste using expanded perlite". Waste Manage. 31(8), pp. 1772-1782.

[23] Sharma A. and Murugan S. 2013, "Investigation on the behaviour of a DI diesel engine fueled with Jatropha Methyl Ester (JME) and Tyre Pyrolysis Oil (TPO) blends". Fuel 108pp. 699-708.

[24] Hariharan S., Murugan S. and Nagarajan G. 2013, "Effect of diethyl ether on Tyre pyrolysis oil fueled diesel engine". Fuel 104pp. 109-115.
[25] Bhatt P. and Patel P. 2012, "Suitability of Tyre Pyrolysis Oil (TPO) as an Alternative Fuel for Internal Combustion Engine". International Journal of Advanced Engineering Research Studies pp. 61-65.

[26] İlkılıç C. and Aydın H. 2011, "Fuel production from waste vehicle tires by catalytic pyrolysis and its application in a diesel engine". Fuel Process Technol 92(5), pp. 1129-1135.

[27] Doğan O., Çelik M. B. and Özdalyan B. 2012, "The effect of tire derived fuel/diesel fuel blends utilization on diesel engine performance and emissions". Fuel 95pp. 340-346.

[28] Tan P., Zhao J., HU Z., LOU D., Du A. and Du D. 2013, "Effects of fuel properties on exhaust emissions from diesel engines". Journal of Fuel Chemistry and Technology 41(3), pp. 347-355.

[29] Khan Z. and Ali S. 2013, "Oxidative desulphurization followed by catalytic adsorption method". South African Journal of Chemical Engineering 18(2), pp. 14-28.

[30] Koc A. B. and Abdullah M. 2014, "Performance of a 4cylinder diesel engine running on tire oil-biodieseldiesel blend". Fuel Process Technol 118pp. 264-269.

[31] Hansen A. C., Zhang Q. and Lyne P. W. 2005, "Ethanoldiesel fuel blends - a review". Bioresour. Technol. 96(3), pp. 277-285.

[32] Hossain A. and Davies P. 2013, "Pyrolysis liquids and gases as alternative fuels in internal combustion engines-A review". Renewable and Sustainable Energy Reviews 21pp. 165-189.

[33] Kumar G., Srinivas G. and Ch A. K. 2012, "Experimental Investigations on Diesel Engine Fueled with Tyre Pyrolysis Oil and Diesel Blends". International Journal of Emerging Trends in Engineering and Developement 7(2), pp. 98-105.

[34] Sharma S. K., Das R. and Sharma A. 2016, "Improvement in the performance and emission characteristics of diesel engine fueled with jatropha methyl ester and tyre pyrolysis oil by addition of nano additives". Journal of the Brazilian Society of Mechanical Sciences and Engineering 38(7), pp. 19071920.

[35] Naima K. and Liazid A. 2013, "Waste oils as alternative fuel for diesel engine: A review". Journal of Petroleum Technology and Alternatives Fuels 4pp. 30-43.

[36] Enweremadu C. and Rutto H. 2010, "Combustion, emission and engine performance characteristics of used cooking oil biodiesel-A review". Renewable and Sustainable Energy Reviews 14(9), pp. 2863-2873.

[37] Jaichandar S. and Annamalai K. 2013, "The status of biodiesel as an alternative fuel for diesel engine-an overview". Journal of Sustainable Energy \& Environment 2(2), pp. 71-75. 